\title{
Molecular and serological detection of Leishmania spp. in horses from an endemic area for canine visceral leishmaniasis in southeastern Brazil ${ }^{1}$
}

\author{
Julia C. Benassi² ${ }^{2}$ Graziella U. Benvenga ${ }^{3}$, Helena L. Ferreira ${ }^{2,3}$, Rodrigo M. Soares ${ }^{3}$, \\ Diogo T. Silva ${ }^{3}$, Vanessa F. Pereira ${ }^{3}$, Vera Letticie A. Ruiz ${ }^{2}$ and Trícia Maria F. de S. Oliveira ${ }^{2,3 *}$ \\ ABSTRACT.- Benassi J.C., Benvenga G.U., Ferreira H.L., Soares R.M., Silva D.T., Pereira V.F., Ruiz \\ V.L.A. \& Oliveira T.M.F.S. 2018. Molecular and serological detection of Leishmania spp. in \\ horses from an endemic area for canine visceral leishmaniasis in southeastern Brazil. \\ Pesquisa Veterinária Brasileira 38(6):1058-1063. Departamento de Medicina Veterinária, \\ Faculdade de Zootecnia e Engenharia de Alimentos, Universidade de São Paulo, Avenida Duque \\ de Caxias Norte 225, Jardim Elite, Pirassununga, SP 13635-900, Brazil. E-mail: tricia@usp.br \\ This study aimed to verify the occurrence of Leishmania spp. and Leishmania (Leishmania) infantum \\ in horses from a visceral leishmaniasis endemic area in Brazil. DNA samples from blood and \\ conjunctival swab (CS) were tested by PCR and Indirect Immunofluorescence Antibody Test \\ (IFAT). Although none of the horses was clinically sick, animals infected by Leishmania spp. \\ were found and some could be characterized as infected by L. (L.) infantum. From 40 horses, \\ $100 \%$ of the animals were positive by blood PCR, 90\% (36/40) by CS PCR, and $2.5 \%(01 / 40)$ \\ in serodiagnosis, by IFAT. Six from these 40 horses were $L$. (L.) infantum positive by blood PCR. \\ Direct sequencing and analysis of amplicons resulted in a sequence to evolutionary analysis. \\ Results indicate the presence of Leishmania spp. and $L$. (L.) infantum infecting healthy horses \\ in Brazil. The presence of Leishmania spp. and $L$. (L.) infantum DNA in asymptomatic horses \\ suggests that they can be important reservoirs of these parasites, a highly relevant finding \\ for the epidemiological surveillance of the diseases they cause.
}

INDEX TERMS: Serology, Leishmania spp., horses, endemic area, canine visceral leishmaniasis, Brazil, Leishmania infantum, PCR, IFAT, evolutionary analysis, parasitoses.

\begin{abstract}
RESUMO.- [Detecção molecular e sorológica de infecção por Leishmania (Leishmania) infantum em cavalos na região Sudeste do Brasil.] 0 estudo objetivou verificar a ocorrência de Leishmania spp. e Leishmania (Leishmania) infantum em cavalos de uma região endêmica para leishmaniose visceral do Brasil. Amostras de DNA de sangue e suabe conjuntival (SC) foram testadas pela PCR e pela Reação de Imunofluorescência Indireta (RIFI). Embora nenhum cavalo estivesse clinicamente doente, animais infectados por Leishmania spp. e L. (L.) infantum foram encontrados em Ilha Solteira/SP. Dos 40 cavalos, 100\% (40/40) foram
\end{abstract}

\footnotetext{
${ }^{1}$ Received on June 23, 2017.

Accepted for publication on July 11, 2017.

2 Departamento de Medicina Veterinária, Faculdade de Zootecnia e Engenharia de Alimentos, Universidade de São Paulo (USP), Avenida Duque de Caxias Norte 225, Jardim Elite, Pirassununga, SP 13635-900, Brazil. *Corresponding author: tricia@usp.br

${ }^{3}$ Programa de Pós-Graduação em Epidemiologia Experimental Aplicada às Zoonoses, Faculdade de Medicina Veterinária e Zootecnia, Universidade de São Paulo (USP), Avenida Prof. Dr. Orlando Marques de Paiva 87, Cidade Universitária, São Paulo, SP 05508-270, Brazil.
}

positivos pela PCR de sangue, $90 \%(36 / 40)$ pela PCR de SC, e 2,5\% (01/40) no sorodiagnóstico, pela RIFI. Seis desses 40 cavalos foram positivos para L. (L.) infantum pela PCR de sangue. 0 sequenciamento direto e a análise dos amplicons resultaram em uma sequência para análise evolutiva. Os resultados indicam a presença de Leishmania spp. e L. (L.) infantum infectando cavalos saudáveis no Brasil. A presença de DNA de Leishmania spp. and L. (L.) infantum em cavalos saudáveis sugere que eles podem ser importantes reservatórios desses parasitas, um achado altamente relevante para a vigilância epidemiológica das doenças que causam.

TERMOS DE INDEXAÇÃO: Sorologia, Leishmania spp., cavalos, endemia, leishmaniose, Leishmania infantum, PCR, IFAT, análise evolutiva, parasitoses.

\section{INTRODUCTION}

Leishmaniasis is caused by obligatory, intracellular, protozoan parasites of the genus Leishmania, and lead to diseases which are clinically and epidemiologically different, depending on the 
Leishmania species involved. They are a global public health problem, especially in tropical and subtropical countries. In these areas, an estimated 300,000 cases of visceral leishmaniasis (VL) and 1 million cases of cutaneous leishmaniasis (CL) occur per year; $95 \%$ of these are concentrated in the Americas, the Mediterranean basin, the Middle East and Central Asia (WHO 2015). In the new world, several species cause cutaneous leishmaniasis (CL), including Leishmania (Viannia) braziliensis and Leishmania (Viannia) amazonensis (Passos et al. 1999).

Leishmania (Leishmania) infantum is the etiological agent of visceral leishmaniasis (VL) in Brazil, a zoonosis potentially fatal to humans and dogs (Shaw 2006). It is a vector-borne disease, transmitted to humans and other animals by the vector's bite, such as the Lutzomyia longipalpis and Lutzomyia cruzi sandflies in Brazil. The sandfly acquires the parasite after hematophagism in infected animals (Shaw 2006). Domestic dogs are considered the primary animal reservoir hosts of the disease and perform an important role in the maintenance of this disease in humans (Quinnell \& Courtenay 2009).

Prevalence of canine VL in endemic areas is around 5.9 to 31.3\% (França-Silva et al. 2003, Lopes et al. 2010, Spada et al. 2014, Leite et al. 2015) and high prevalence of canine infection is associated with a higher risk of the disease in humans (Werneck 2008). In spite of being mainly described in dogs and humans, other mammals can also be infected by the parasite and suffer disease, including cats, bats and horses (Savani et al. 2004, Vides et al. 2011, Soares et al. 2013).

Since the first evidence of horses infected with Leishmania in Argentina (Mazza 1927) some authors suggest that horses, donkeys and mules can possible be accidental hosts or even Leishmania spp. reservoirs and can play an important role in the epidemiology of leishmaniases. It is noteworthy to point out that the Leishmania species described in Argentina was $L$. (V.) braziliensis, the main agent of cutaneous leishmaniasis (CL) in Brazil. Leishmania infections in horses, related to $L$. (V.) braziliensis has been described in many states of Brazil and it is suspected that horses are the primary reservoirs of this parasite (Aguilar et al. 1986, Vexenat et al. 1986, Falqueto et al. 1987, Yoshida et al. 1988, Brandão-Filho et al. 2003, Vedovello-Filho et al. 2008, Soares et al. 2013).

From the 80 s to the present day, Brazil is facing a continuing increase in VL cases. Around 3,500 cases are recorded annually and the incidence rate is $2.0 / 100,000$ inhabitants and lethality is increasing, from $3.2 \%$ in 2000 to $7.1 \%$ in 2012 (Brasil 2015). Despite VL has a national control program in Brazil that includes dog culling, the disease is growing and expanding in the country (Nascimento et al. 2008, Von Zuben et al. 2014, Brasil 2015).

To the failure in VL control program, some reasons are suggested: the lack of diagnostic tests to differentiate infectious and non-infectious dogs, non-vector transmission routes and possible new reservoirs (Quinnell \& Courtenay 2009). While L. (L.) infantum infection in humans and domestic dogs has long been known, other domestic animals received less attention (Quinnell \& Courtenay 2009). Cases of $L$. (L.) infantum infecting horses in Europe were reported (Koehler et al. 2002, Solano-Gallego et al. 2003, Rolão et al. 2005, Gama et al. 2014) and in 2013, the first report of $L$. (L.) infantum infecting horses in Brazil was done (Soares et al. 2013). In most of the cases cited above the animals presented cutaneous lesions, probably due to the presence of the parasite in the skin. In this report, healthy horses were encountered positives to Leishmania spp. and $L$. (L.) infantum, enhancing their role as leishmaniases reservoirs.

The aim of this study was to verify the occurrence of Leishmania spp. and Leishmania (Leishmania) infantum in horses from a VL endemic area in the state of São Paulo, Brazil by PCR on DNA extracted from blood samples and conjunctival swab (CS) and by Indirect Immunofluorescence Antibody Test (IFAT).

\section{MATERIALS AND METHODS}

Ethics statement. The present study was approved by the Ethics Committee for the Use of Animals at the School of Veterinary Medicine and Animal Science of the University of São Paulo and was performed in compliance with national guidelines (process number 2361/2013). All horse owners consented to have their animals sampled.

Samples. We obtained biological samples from 40 horses from the county of Ilha Solteira $\left(20^{\circ} 25^{\prime} 58^{\prime \prime}\right.$ S, 5120'33”W), São Paulo State, Brazil using a convenience sampling method, between the years of 2012 and 2013. The clinical status of the horses was evaluated during sample collection.

Blood, serum and CS from both eyes were collected from the 40 horses. For the harvesting of conjunctival cells, sterile swabs manufactured for use in bacteriological isolation were used. For each horse, a sterile swab was rubbed on the lower conjunctiva of both eyes to collect cells. The extremities of these swabs were separated and stored at $4^{\circ} \mathrm{C}$ until processing (up to one month) in $1.5 \mathrm{~mL}$ microtubes, free of DNAse or RNAse.

Blood samples were collected from the jugular vein in EDTA tube; $5 \mathrm{~mL}$ were collected for the serological assay and DNA extraction.

Immunofluorescence Antibody Test (IFAT). The IFAT was performed using a methodology previously described (Oliveira et al. 2008). Antigen slides previously prepared for Leishmania chagasi (syn. Leishmania infantum) (Imunoteste ${ }^{\circledR}$, Leishmania chagasi, Imunodot, Jaboticabal/SP, Brasil) were used. Positive and negative controls were added to each test slide. Serial dilutions of each serum were performed. The IFAT used an anti-horse-IgG (immune globulin G), conjugated to fluorescein isothiocyanate (Sigma-Aldrich, Bellefonte, PA, USA, catalog n-F7759), and diluted according to the manufacturer's recommendations. Reactive samples diluted at equal or higher than 1:40 were considered positive (Soares et al. 2013).

DNA extraction. DNA from CS was purified using the salting-out technique described by Lahiri \& Numberger Junior (1991), while DNA from blood was purified using the Illustra Blood Genomic Prep Mini Spin ${ }^{\circledR}$ kit (GE Healthcare Life Sciences ${ }^{\circledR}$, Uppsala, Sweden, catalog $\mathrm{n}$-28904264), according to the manufacturer's recommendations. Between extraction and analysis, DNA samples were stored at $-20^{\circ} \mathrm{C}$.

DNA amplification. The PCR reactions were performed in triplicate using a previously described oligonucleotide pair to amplify a conserved 120-base pair region of the Leishmania spp. kinetoplast minicircle: 13 A 5' -dGTG GGG GAG GGG CGT TCT-3' and 13B 5'-dATT TTA CAC CAA CCC CCA GTT-3 (Rodgers et al. 1990) and a $L$. (L.) infantum specific 447-base pair region: MC1 5'-dGTT AGC CGA TGG TGG TCT TG-3' and MC2 5'dCAC CCA TTT TTC CGA TTT TG-3' (Cortes et al. 2004). The reaction mixture was the same for both pair of primers and consisted of $5 \mathrm{U} / \mu \mathrm{L}$ of Platinum Taq DNA Polymerase (Invitrogen, Carlsbad, CA, USA, catalog number 10966-030), 2.5 $\mu \mathrm{L}$ of $1 \mathrm{X}$ PCR buffer (200mM Tris- $\mathrm{HCl} ; 500 \mathrm{mM}, \mathrm{pH}$ 8.4), $1.5 \mathrm{mM}$ of $\mathrm{MgCl}_{2}, 0.5 \mu \mathrm{L}$ for dNTP's ( $10 \mathrm{mM}$ each), $1,5 \mu \mathrm{L}$ of each primer $(10 \mathrm{pmol} / \mu \mathrm{L}), 12.25 \mu \mathrm{L}$ of ultrapure water and $2.5 \mu \mathrm{L}$ of DNA 
extracted from blood in a total volume of $25 \mu \mathrm{L}$. The amplification reactions were performed in a thermocycler (VeritiDx Thermal Cycler, Applied Biosystems, Foster City, CA, USA) with initial denaturation at $94^{\circ} \mathrm{C}(3 \mathrm{~min})$, then 35 cycles of denaturation at $94^{\circ} \mathrm{C}$ (40sec), annealing at $56^{\circ} \mathrm{C}(30 \mathrm{sec})$, and extension at $72^{\circ} \mathrm{C}(30 \mathrm{sec})$, followed by a final extension at $72^{\circ} \mathrm{C}(5 \mathrm{~min})$ to Leishmania spp. To $L$. (L.) infantum the initial denaturation was $94^{\circ} \mathrm{C}(2 \mathrm{~min})$, then 40 cycles of denaturation at $94^{\circ} \mathrm{C}(20 \mathrm{sec})$, annealing at $60^{\circ} \mathrm{C}(20 \mathrm{sec})$, and extension at $72^{\circ} \mathrm{C}(30 \mathrm{sec})$, followed by a final extension at $72^{\circ} \mathrm{C}$ ( $5 \mathrm{~min}$ ). To visualize the bands, $8 \mu \mathrm{L}$ of the amplified products was subjected to electrophoresis in a $2 \%$ agarose gel stained with SYBR safe (Invitrogen, Carlsbad, CA, USA, catalog number 33102). DNA of L. (L.) infantum (MCAN/BR/1984/CCC-17.481), kindly provided by Fundação Oswaldo Cruz (FIOCRUZ), was used as a positive control, while deionized water was used as a negative control.

Sequencing. After observation through electrophoresis on a $2 \%$ agarose gel, the PCR products were excised from the gel and purified by using GE Healthcare kit (Illustra, GFX PCR DNA and GEL Band Purification Kit), according to the manufacturer's instructions. DNA sequencing was performed using 20ng/uL of purified PCR products and $5 \mu \mathrm{M}$ of each primer at DNA Sequencing Service of the Research Center on the Human Genome and Stem Cells, Biologic Institute (IB), University of Sao Paulo (USP).

Chromatograms obtained with the forward and reverse primers were assembled by Sequence Scanner Software 2 v2.2. The contig was submitted to BLAST search, and hit sequences were retrieved for evolutionary analysis. Only sequences with more than $90 \%$ query coverage were included in the analysis. Forward and reverse sequences were manipulated by Clustal $\mathrm{W}$ available in the suite BioEdit Sequence Alignment Editor version 7.1.11 (Hall 1999). Obtained sequence was also aligned with available sequences in GenBank (http://www.ncbi.nlm.nih.gov/Genbank/index.html) by using Clustal W in BioEdit Sequence Alignment Editor version 7.1.11.

Phylogenetic analysis. The analysis included 37 taxons. The evolutionary history was inferred by using the Maximum Likelihood method based on the Tamura 3-parameter model. A discrete Gamma distribution was used to model evolutionary rate differences among sites and the branches were supported after the bootstrap test (1.000 replicates) (Felsenstein 1985). Evolutionary analysis were conducted in MEGA6 (Tamura et al. 2013). Final tests were laid out using Figtree software, v1.4.2.

\section{RESULTS}

Although none of the 40 horses showed clinical signs consistent with equine leishmaniasis, 100\% (40/40) were blood-PCR positive, 90\% (36/40) CS-PCR positive, 2.5\% (01/40) IFAT positive at 1:80 titration and 15\% (06/40) Leishmania (Leishmania) infantum blood-PCR positive.

Direct sequencing and analysis of amplicons resulted in a $422 \mathrm{bp}$ sequence from one horse. These sequences were deposited in GenBank under accession number KT878648. The best alignment score obtained after BLAST search using this sequence as the query was with the sequence KF695386, which was obtained from naturally L. (L.) infantum infected dog from an endemic area of Brazil. These two sequences have 99.3\% identity. The evolutionary relationships of KT878648 with other 37 sequences obtained after BLAST search were shown in the Figure 1. The criterion for including sequences in the phylogenetic analysis was using sequences with $100 \%$ query coverage. By using BLAST, only sequences from L. infantum,
L. donovani and L. major were retrieved, which impaired rooting the tree.

\section{DISCUSSION}

In the present study, we encountered horses showing no clinical signs of disease, infected by Leishmania spp. and L. (L.) infantum. In a blast search, our sequence finds regions of similarity between biological sequences of L. infantum, L. donovani and L. major. No other Leishmania species was found. We cannot explain about L. major sequences encoutered at the blast search. We believe that they probably are also L. infantum or L. donovani sequences. In spite of been reported infected by $L$. (L.) infantum in Europe, in Brazil, the most common infection described in horses is by L. (V.) braziliensis. Prior to this study, L. (L.) infantum in horses was reported for the first time in the Americas in two animals with skin lesions and one horse with locomotors problems (Soares et al. 2013). Other studies, in VL endemic areas, showed horses with antibodies against Leishmania spp., which suggests that these animals can be also infected by L. (L.) infantum in these areas (Feitosa et al. 2012).

Only one of these $L$. (L.) infantum positives horses was seropositive by IFAT, the others were seronegative, in spite of being Leishmania spp. PCR positives. According to Koehler et al. (2002), the absence of specific antibodies against Leishmania spp. in infected horses is common. Positive PCR with negative serology can be obtained in acute infection, or in some immune diseases (Truppel et al. 2014). Asymptomatic cases of VL are common in dogs and humans, including seronegative dogs that can be PCR positives (Solano-Gallego et al. 2011). The presence of the parasite in asymptomatic dogs, with absence of antibodies indicates that they have the infection, but they may never be sick (Solano-Gallego et al. 2011). However, in horses, as well of no other characteristic of VL in this species, it is not well known.

Therefore, our results indicate that animals had either an acute Leishmania spp. infection or a chronic infection from a species other than $L$. (L.) infantum, in some cases. The county of Ilha Solteira is an endemic area for VL and 31.3\% of its dogs in rural areas are serum reactive to L. infantum (Spada et al. 2014). Although to date there have been no reports of Leishmania infected horses in the city, according to the Epidemiological Surveillance office (CVE 2015a), one human case of CL and one of VL were registered between 2010 and 2013 (CVE 2015b), with CVL prevalence rates ranging from $31.3 \%$ to $37.6 \%$ (Paulan et al. 2013, Spada et al. 2014).

This is the first report describing CS use to detect Leishmania spp. in horses. Prior to this study, CS was already an effective method of diagnosing a number of other etiologic agents that have tropism for ocular conjunctiva in horses, or microorganisms that are part of local microbiota (Samuelson et al. 1984, Mair \& Wills 1992, Pisani et al. 1997, Borchers et al. 2006). In addition, CS had been shown to effectively diagnose leishmaniasis in dogs (Solano-Gallego et al. 2009, Leite et al. 2010, Ferreira et al. 2012), being considered more sensitive than blood in dogs (Solano-Gallego et al. 2011). Different from our results, blood PCR was more sensitive to detect Leishmania spp. and L. (L.) infantum in horses than CS-PCR.

Horses are commonly used for work in urban and rural areas of Brazil. Seropositive results from horses in Araçatuba/SP (Feitosa etal. 2012) and in different countries from 


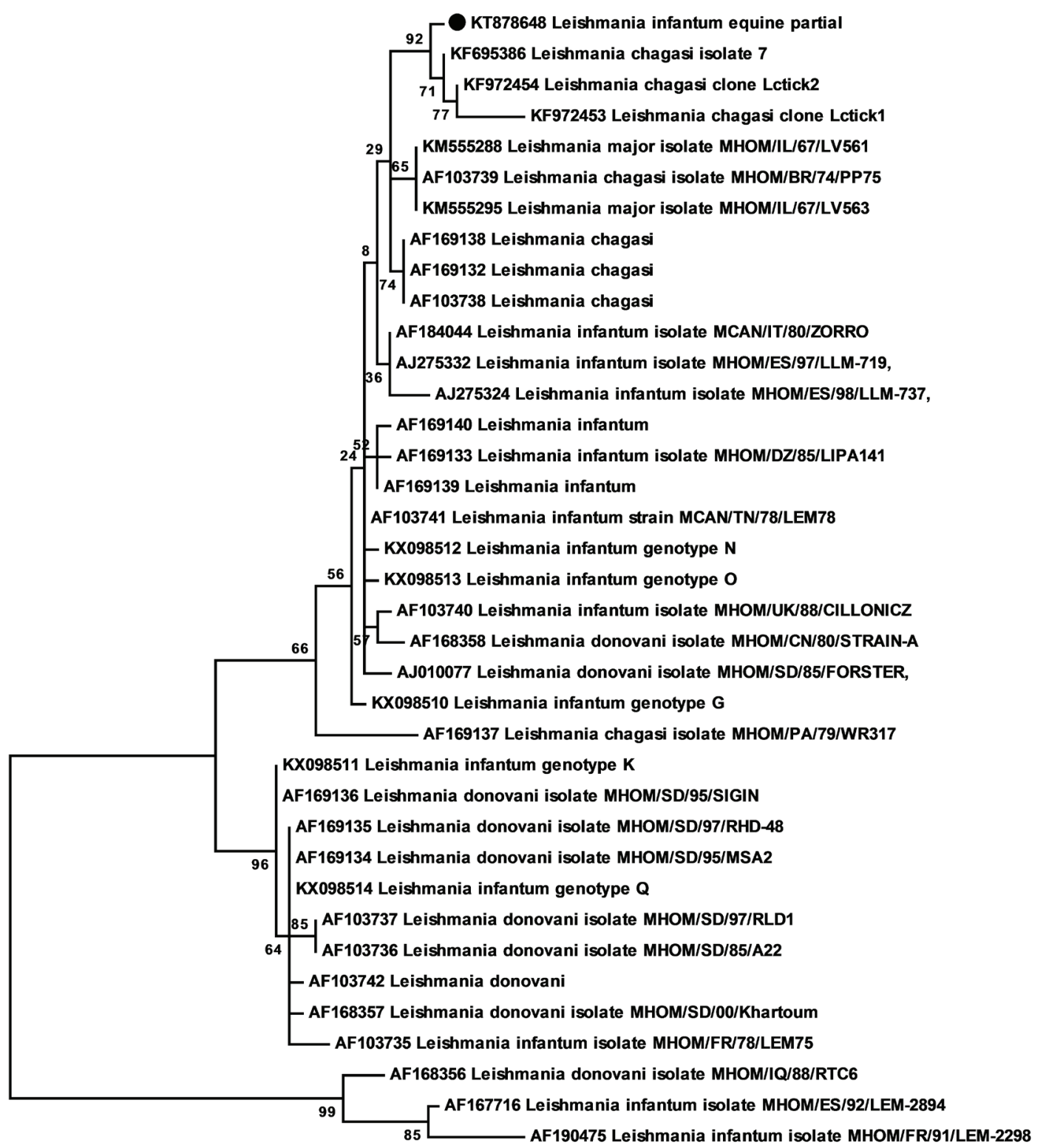

0.02

Fig.1. Evolutionary relationships of taxa. The evolutionary history was inferred using the Maximum Likelihood method based on the Tamura 3-parameter model. A discrete Gamma distribution was used to model evolutionary rate differences among sites and the branches were supported after bootstrap test (1.000 replicates). The tree is drawn to scale, with branch lengths in the same units as those of the evolutionary distances used to infer the phylogenetic tree. The analysis involved 37 nucleotide sequences. Sequence obtained in this study is marked with $(\bullet)$. Evolutionary analyses were conducted in MEGA6.

the state of Paraná (Vedovello-Filho et al. 2008, Truppel et al. 2014) suggest that horses likely attract sandflies that transmit leishmaniasis, because they probably serve as a source of blood. A study conducted in a CL endemic region of Brazil, the authors suggest that horses could be source of blood for phlebotomines in peridomestic environment and hence can be the primary reservoirs of $L$. (V.) braziliensis (Truppel et al. 2014).

In a VL transmission area, a study to evaluate Lu. longipalpis feeding preference observed that most sandflies preferred birds, rodents and humans (Missawa et al. 2008). Others authors observed that in the feeding preferences of Lu. longipalpis birds was first and dogs second followed by horses, skunks, sheep, goats, rodents and man (Afonso et al. 2012), showing that horses are a blood source for these sandflies. Factors like deforestation, uncontrolled growth of urban areas and rapid vector adaptation to the new environment sets off the vector search for other sources of blood (Afonso et al. 2012). Quinnell et al. (1992) says that the attractiveness of different hosts to Lu. longipalpis are largely a function of their relative sizes. Therefore, it is suggested that, in some regions, horses 
can play a role in the disease cycle. Our finding supports this suggestion, since healthy horses were found infected with L. (L.) infantum in VL endemic areas.

Our results show that Leishmania may infect a large percentage of healthy horses, in a VL-endemic area in Brazil. In addition, detection of Leishmania in blood and epithelial cells of the conjunctiva supports previous inquiries about the role of horses as a source of Leishmania infection for sand flies, in urban and rural areas, which can then transmit it to humans.

\section{CONCLUSION}

The detection of Leishmania spp. and Leishmania (Leishmania) infantum DNA in horses, linked with the absence of clinical signs in the animals, suggests that horses are acting as healthy parasite carriers for leishmaniasis. This knowledge has the potential to advance our understanding of the epidemiology of leishmaniasis in the New World, as well as efforts for disease prevention and control.

Acknowledgements.- Current research was funded by Fundação de Amparo à Pesquisa do Estado de São Paulo (FAPESP) grant n. 2011/00147-6 and n. 2013/19821-4.

\section{REFERENCES}

Afonso M.M.D.S., Duarte R., Miranda J.C., Caranha L. \& Rangel E.F. 2012. Studies on the feeding habits of Lutzomyia (Lutzomyia) longipalpis (Lutz and Neiva. 1912. (Diptera: Psychodidae: Phlebotominae) populations from endemic areas of American visceral leishmaniasis in northeastern Brazil. J. Trop. Med. 2012:1-5. http://dx.doi.org/10.1155/2012/858657. PMid:22315621.

Aguilar C.M., Rangel E.F. \& Deane L.M. 1986. Cutaneous leishmaniasis is frequent in equines from an endemic area in Rio de Janeiro, Brazil. Mem. Inst. Oswaldo Cruz 81(4):471-472. http://dx.doi.org/10.1590/S007402761986000400015. PMid:3613980.

Borchers K., Ebert M., Fetsch A., Hammond T. \& Sterner-Kock A. 2006. Prevalence of equine herpesvirus type 2 (EHV-2) DNA in ocular swabs and its cell tropism in equine conjunctiva. Vet. Microbiol. 118(3/4):260266. http://dx.doi.org/10.1016/j.vetmic.2006.07.024. PMid:16996233.

Brandão-Filho S.P., Brito M.E., Carvalho F.G., Ishikaw E.A., Cupolillo E., FloeterWinter L. \& Shaw J.J. 2003. Wild and synantropic hosts of Leishmania (Viannia) braziliensis in the endemic cutaneous leishmaniasis locality of Amaraji, Pernambuco State, Brazil. Trans. R. Soc. Trop. Med. Hyg. 97(3):291-296. http://dx.doi.org/10.1016/S0035-9203(03)90146-5. PMid:15228244.

Brasil 2015. Leishmaniose Visceral: situação epidemiológica, dados. Ministério da Saúde, Brasília. Available at <http://portalsaude.saude.gov.br/index. php/o-ministerio/principal/leia-mais-o-ministerio/726-secretaria-svs/ vigilancia-de-a-az/leishmaniose-visceral-lv/11334-situacao-epidemiologicadados> Access on Mar. 23, 2015.

Cortes S., Rolão N., Ramada J. \& Campino L. 2004. PCR as a rapid and sensitive tool in the diagnosis of human and canine leishmaniasis using Leishmania donovani s.l.-specific kinetoplastid primers. Trans. R. Soc. Trop. Med. Hyg. 98(1):12-17. http://dx.doi.org/10.1016/S0035-9203(03)00002-6. PMid:14702834.

CVE 2015a. Leishmaniose Tegumentar Americana Humana: casos confirmados, segundo GVE e município de residência e ano de diagnóstico, 2007 a 25/04/2013. Centro de Vigilância Epidemiológica do Estado de São Paulo, São Paulo. Available at <http://www.cve.saude.sp.gov.br/htm/zoo/ lta_dados.html> Access on Apr. 6, 2015.

CVE 2015b. Leishmaniose Visceral Americana Humana: distribuição do número de casos e óbitos de LVA segundo município e GVE de infecção,
2010 a 02/05/2013. Centro de Vigilância Epidemiológica do Estado de São Paulo, São Paulo. Available at <http://www.cve.saude.sp.gov.br/htm/ zoo/lvah_lpi.htm> Access on Apr. 6, 2015.

Falqueto A., Varejão J.B.M. \& Sessa P.A. 1987. Cutaneous leishmaniasis in a horse (Equus caballus) from endemic area in the state of Espírito Santo, Brazil. Mem. Inst. Oswaldo Cruz 82(3):443. http://dx.doi.org/10.1590/ S0074-02761987000300020. PMid:3507577.

Feitosa F.L.F., Leal J., Mendes L.C.N., Peiró J.R., Perri S.H.V., Lima V.M.F. \& Marcondes M. 2012. Estudo soroepidemiológico de leishmaniose em equinos na região de Araçatuba-SP, Brasil, área endêmica para leishmaniose visceral. Braz. J. Vet. Res. Anim. Sci. 49(6):500-502. http://dx.doi.org/10.11606/ issn.1678-4456.v49i6p500-502.

Felsenstein J. 1985. Confidence-limits on phylogenies: an approach using the bootstrap. Evolution 39(4):783-791.http://dx.doi.org/10.1111/j.1558-5646.1985. tb00420.x. PMid:28561359.

Ferreira S.A., Leite R.S., Ituassu L.T., Almeida G.G., Souza D.M., Fujiwara R.T., Andrade A.S.R. \& Melo M.N. 2012. Canine skin and conjunctival swab samples for the detection and quantification of Leishmania infantum DNA in an endemic urban area in Brazil. PLoS Negl. Trop. Dis. 6(4):e1596. http:// dx.doi.org/10.1371/journal.pntd.0001596. PMid:22506084.

França-Silva J.C., Costa R.T., Siqueira A.M., Machado-Coelho G.L.L., Costa C.A., Mayrink W., Vieira E.P., Costa J.S., Genaro O. \& Nascimento E. 2003. Epidemiology of canine visceral leishmaniosis in the endemic area of Montes Claros Municipality, Minas Gerais State, Brazil. Vet. Parasitol. 111(2/3):161-173. http://dx.doi.org/10.1016/S0304-4017(02)003515. PMid:12531292.

Gama A., Elias J., Ribeiro A.J., Alegria N., Schallig H.D.F.H., Silva F., Santarém N., Cardoso L. \& Cotovio M. 2014. Cutaneous leishmaniosis in a horse from northern Portugal. Vet. Parasitol. 200(1-2):189-192. http://dx.doi. org/10.1016/j.vetpar.2013.12.005. PMid:24388338.

Hall T.A. 1999. BioEdit: a user-friendly biological sequence alignment editor and analysis program for Windows 95/98/NT. Nucleic Acids Symp. Series 41:95-98.

Koehler K., Stechele M., Hetzel U., Domingo M., Schönian G., Zahner H. \& Burkhardt E. 2002. Cutaneous leishmaniosis in a horse in southern Germany caused by Leishmania infantum. Vet. Parasitol. 109(1/2):9-17. http://dx.doi.org/10.1016/S0304-4017(02)00246-7. PMid:12383621.

Lahiri D.K. \& Numberger Junior J.I. 1991. A rapid non-enzymatic method for the preparation of HMW DNA from blood for RFLP studies. Nucleic Acids Res. 19(19):5444. http://dx.doi.org/10.1093/nar/19.19.5444. PMid:1681511.

Leite R.S., Ferreira S.A., Ituassu L.T., Melo M.N. \& Andrade A.S. 2010. PCR diagnosis of visceral leishmaniasis in asymptomatic dogs using conjunctival swab samples. Vet Parasitol.170(3/4):201-206. http://dx.doi.org/10.1016/j. vetpar.2010.02.020. PMid:20227834.

Leite R.S., Souza N.A., Barbosa A.D., Ferreira A.L.C. \& De Andrade A.S.R. 2015. Evaluation of conjunctival swab as a mass-screening tool for molecular diagnosis of canine visceral leishmaniasis. Parasitol. Res. 114(6):22552262. http://dx.doi.org/10.1007/s00436-015-4418-y. PMid:25782681.

Lopes E.G.P., Magalhães D.F., Silva J.A., Haddad J.P.A. \& Moreira E.C. 2010. Temporal and spatial distribution of leishmaniasis in humans and dogs from Belo Horizonte/MG, 1993-2007. Arq. Bras. Med. Vet. Zootec. 62(5):10621071. http://dx.doi.org/10.1590/S0102-09352010000500007.

Mair T.S. \& Wills J.M. 1992. Chlamydia psittaci infection in horses: results of a prevalence survey and experimental challenge. Vet. Rec. 130(19):417-419. http://dx.doi.org/10.1136/vr.130.19.417. PMid:1609475.

Mazza S. 1927. Leishmaniasis cutánea en el caballo y nueva observación de la misma en el perro. Bol. Univ. B. Aires 3:462-464.

Missawa N.A., Lorosa E.S. \& Dias E.S. 2008. Preferência alimentar de Lutzomyia longipalpis (Lutz and Neiva, 1912) em área de transmissão de leishmaniose visceral em Mato Grosso. Revta Soc. Bras. Med. Trop. 41(4):365-368. http://dx.doi.org/10.1590/S0037-86822008000400008. PMid:18853008. 
Nascimento E.L.T., Martins D.R., Monteiro G.R., Barbosa J.D., Ximenes M.F.F.M., Maciel B.L., Duarte I. \& Jerônimo S.M.B. 2008. Forum: geographic spread and urbanization of visceral leishmaniasis in Brazil. Postscript: new challenges in the epidemiology of Leishmania chagasi infection. Cad. Saúde Pública 24(12):2964-2967. http://dx.doi.org/10.1590/S0102311X2008001200028. PMid:19082290.

Oliveira T.M.F.S., Furuta P.I., Carvalho D. \& Machado R.Z. 2008. Study of crossreactivity in serum samples from dogs positive for Leishmania sp., Babesia canis and Ehrlichia canis in enzyme-linked immunosorbent assay and indirect fluorescent antibody test. Revta Bras. Parasitol. Vet. 17(1):7-11. http://dx.doi.org/10.1590/S1984-29612008000100002. PMid:18554433.

Passos V.M.A., Fernandes O., Lacerda P.A.F., Volpini A.C., Gontijo C.M.F., Degrave W. \& Romanha A.J. 1999. Leishmania (Viannia) braziliensis is the predominant specie infecting pacientes with american cutaneous leishmaniasis in the state of Minas Gerais, Southeast, Brazil. Acta Trop. 72(3):251-258. http:// dx.doi.org/10.1016/S0001-706X(98)00100-4. PMid:10232781.

Paulan S.C., Lins A.G.S., Tenório M.S., Silva D.T., Pena H.F.J., Machado R.Z., Gennari S.M. \& Buzetti W.A.S. 2013. Seroprevalence rates of antibodies against Leishmania infantum and other protozoan and rickettsial parasites in dogs. Revta Bras. Parasitol. Vet. 22(1):162-166. http://dx.doi.org/10.1590/ S1984-29612013000100031. PMid:24252965.

Pisani E.H.R., Barros P.S.M. \& Ávila F.A. 1997. Microbiota conjuntival normal de equinos. Braz. J. Vet. Res. Anim. Sci. 34(5):261-265. http://dx.doi. org/10.11606/issn.2318-3659.v34i5p261-265.

Quinnell R.J. \& Courtenay 0. 2009. Transmission, reservoir hosts and control of zoonotic visceral leishmaniasis. Parasitology 136(14):1915-1934. http:// dx.doi.org/10.1017/S0031182009991156. PMid:19835643.

Quinnell R.J., Dye C. \& Shaw J.J. 1992. Host preferences of the phlebotomine sandfly Lutzomyia longipalpis in Amazonian Brazil. Med. Vet. Entomol. 6(3):195-200. http://dx.doi.org/10.1111/j.1365-2915.1992.tb00606.x. PMid:1421498.

Rodgers M.R., Popper S.J. \& Wirth D.F. 1990. Amplification of kinetoplast DNA as a tool in the detection and diagnosis of Leishmania. Exp. Parasitol. 71(3):267-275. http://dx.doi.org/10.1016/0014-4894(90)90031-7. PMid:2170165.

Rolão N., Martins M.J., João A. \& Campino L. 2005. Equine infection with Leishmania in Portugal. Parasite 12(2):183-186. http://dx.doi.org/10.1051/ parasite/2005122183. PMid:15991833.

Samuelson D.A., Andresen T.L. \& Gwin R.M. 1984. Conjunctival fungal flora in horses, cattle, dogs, and cats. J. Am. Vet. Med. Assoc. 184(10):1240-1242. PMid:6539761.

Savani E.S., Oliveira Camargo M.C., Carvalho M.R., Zampieri R.A., Santos M.G., D’Auria S.R., Shaw J.J. \& Floeter-Winter L.M. 2004. The first record in the Americas of an autochthonous case of Leishmania (Leishmania) infantum chagasi in a domestic cat (Felix catus) from Cotia Country, São Paulo State, Brazil. Vet. Parasitol. 120(3):229-233. http://dx.doi.org/10.1016/j. vetpar.2004.01.008. PMid:15041097.

Shaw J.J. 2006. Further thoughts on the use of tech name Leishmania (Leishmania) infantum chagasi dor the aetiological agent of American visceral leishmaniasis. Mem. Inst. Oswaldo Cruz 101(5):577-579. http:// dx.doi.org/10.1590/S0074-02762006000500017. PMid:17072466.

Soares I.R., Silva S.O., Moreira F.M., Prado L.G., Fantini P., Maranhão R.P.A., SilvaFilho J.M., Melo M.N. \& Palhares M.S. 2013. First evidence of autochthonous cases of Leishmania (Leishmania) infantum in horse (Equus caballus) in the Americas and mixed infection of Leishmania infantum and Leishmania (Viannia) braziliensis. Vet. Parasitol. 197(3/4):665-669. http://dx.doi. org/10.1016/j.vetpar.2013.06.014. PMid:23845306.
Solano-Gallego L., Fernández-Bellon H., Serra P., Gállego M., Ramis A., Fondevila D. \& Ferrer L. 2003. Cutaneous leishmaniosis in three horses in Spain. Equine Vet. J. 35(3):320-323. http://dx.doi.org/10.2746/042516403776148336. PMid:12755438.

Solano-Gallego L., Koutinas A., Miró G., Cardoso L., Pennisi M.G., Ferrer L., Bourdeau P., Oliva G. \& Baneth G. 2009. Directions for the diagnosis, clinical staging, treatment and prevention of canine leishmaniosis. Vet Parasitol. 165(1/2):1-18.http://dx.doi.org/10.1016/j.vetpar.2009.05.022. PMid:19559536.

Solano-Gallego L., Miró G., Koutinas A., Cardoso L., Pennisi M.G., Ferrer L., Bourdeau P., Oliva G. \& Baneth G. 2011. LeishVet guidelines for the practical management of canine leishmaniosis. Parasit. Vectors 4(1):86. http:// dx.doi.org/10.1186/1756-3305-4-86. PMid:21599936.

Spada J.C.P., Silva D.T., Martins K.R.R., Rodas L.A.C., Alves M.L., Faria G.A., Buzutti M.C., Silva H.R. \& Starke-Buzetti W.A. 2014. Occurrence of Lutzomyia longipalpis (Phlebotominae) and canine visceral leishmaniasis in a rural area of Ilha Solteira, SP, Brazil. Revta Bras. Parasitol. Vet. 23(4):456-462. http://dx.doi.org/10.1590/S1984-29612014087. PMid:25517523.

Tamura K., Stecher G., Peterson D., Filipski A. \& Kumar S. 2013. MEGA6: molecular evolutionary genetics analysis version 6.0. Mol Biol. Evol. 30(12):27252729. http://dx.doi.org/10.1093/molbev/mst197. PMid:24132122.

Truppel J.H., Otomura F., Teodoro U., Massafera R., Costa-Ribeiro M.C.V., Catarino C.M., Dalagrana L., Costa Ferreira M.E.M. \& Thomaz-Soccol V. 2014. Can equids be a reservoir of Leishmania brazilensis in endemic areas? Plos One 9(4):e93731. http://dx.doi.org/10.1371/journal.pone.0093731. PMid:24721908.

Vedovello-Filho D., Jorge F.A., Lonardoni M.V.C., Teodoro U. \& Silveira T.G.V. 2008. American cutaneous leishmaniasis in horses from endemic areas in the north-central mesoregion of Paraná State, Brazil. Zoonoses Public Health 55(3):149-155. http://dx.doi.org/10.1111/j.1863-2378.2008.01106.x. PMid:18331518.

Vexenat J.A., Barretto A.C., Rosa A.D.C.O., Sales C.C. \& Magalhães A.V. 1986. Infecção natural de Equus asinus por Leishmania braziliensis braziliensis. Bahia, Brasil. Mem. Inst. Oswaldo Cruz 81(2):237-238. http://dx.doi. org/10.1590/S0074-02761986000200016. PMid:3587004.

Vides J.P., Schwardt T.F., Sobrinho L.S.V., Marinho M., Laurenti M.D., Biondo A.W., Leutenegger C. \& Marcondes M. 2011. Leishmania chagasi infection in cats with dermatologic lesions from an endemic area of visceral leishmaniosis in Brazil. Vet. Parasitol. 178(1/2):22-28. http://dx.doi.org/10.1016/j. vetpar.2010.12.042. PMid:21282011.

Von Zuben A.P., Angerami R.N., Castagna C., Baldini M.B. \& Donalisio M.R. 2014. The first canine visceral leishmaniasis outbreak in Campinas, State of São Paulo Southeastern Brazil. Revta Soc. Bras. Med. Trop. 47(3):385388. http://dx.doi.org/10.1590/0037-8682-0126-2013. PMid:25075492.

Werneck G.L. 2008. Forum: geographic spread and urbanization of visceral leishmaniasis in Brazil, introduction. Cad. Saúde Pública 24(12):2937-2940. http://dx.doi.org/10.1590/S0102-311X2008001200023. PMid:19082285.

WHO 2015. Leishmaniasis. World Health Organization, Geneva. Available at <http://www.who.int/leishmaniasis/en/> Access on Apr. 6, 2015.

Yoshida E.L.D.A., Marques D.A.S., Stolf H.O., Barsotti L.A., Bueno M.M.F. \& Sogayar R. 1988. Infecção natural de Equus caballus por Leishmania sp-São Paulo, Brasil. Revta Inst. Med. Trop. 30(2):79-80. http://dx.doi. org/10.1590/S0036-46651988000200004. 